\title{
The Impact of Corporate Social Responsibility on Employee Commitment: Mediating role of Meaningful Work and Positive Affect
}

\author{
Weerasekara N. ${ }^{1}$ and Ajward R. ${ }^{2}$ \\ ${ }^{1}$ Department of Business Administration, University of Sri Jayewardenepura, Sri Lanka \\ ${ }^{2}$ Department of Accounting, University of Sri Jayewardenepura, Sri Lanka \\ ${ }^{1}$ nikeshalawe@sjp.ac.lk, ${ }^{2}$ ajward@sjp.ac.lk
}

\begin{abstract}
This paper aims to theoretically explain the relationships between Corporate Social Responsibility (CSR) and employee commitment using both Social Identity Theory (SIT) and Social Exchange Theory (SET) by developing a conceptual model which incorporates mediation effects of meaningful work and positive affect. Further, this paper highlights the importance of examining employees' perception of CSR activities in the licensed commercial banking sector. A structured questionnaire that was developed based on a comprehensive review of literature and refined using both expert opinions and a pilot survey was used for data collection. Sample comprised of 410 respondents, and a convenience sampling strategy was used to secure these responses from 13 local licensed commercial banks in Sri Lanka. Structural equation modelling was utilized to test the proposed relationships. The findings indicate that there are significant $(\mathrm{p}<0.05)$ positive relationships between CSR perceptions and employee commitment. Furthermore, meaningful work and positive affect were found to partially mediate the relationship between CSR and employee commitment. In terms of theoretical significance this study filled a gap by utilizing both SIT and SET in explaining relationships between CSR perceptions and employee commitment. Findings also contribute to the extant empirical literature on CSR perceptions and employee commitment particularly in the banking sector. Moreover, this study adds new insights on mediating capability of psychologically related variables.
\end{abstract}

Keywords: Corporate social responsibility, Employee commitment, Meaningful work, Positive affect

Copyright: (C) 2020 Weerasekara N. and Ajward R. This is an open access article distributed under the Creative Commons Attribution License, which permits unrestricted use, distribution, and reproduction in any medium, provided the original work is properly cited.

Correspondence: nikeshalawe@sjp.ac.lk

ORCID of authors: Weerasekara N - https://orcid.org/0000-0002-8090-7408

Ajward R - https://orcid.org/0000-0002-7001-9335

DOI: http://doi.org/10.4038/kjm.v9i1.7622 


\section{Introduction}

Due to increasing competition in the current world, companies search for factors that would enable them to sustain competitive advantage where corporate reputation is one such factor which is derived through engaging in Corporate Social Responsibility (CSR) activities (Engizek \& Yasin, 2017; Khaleel, Chelliah, Rauf \& Jamil, 2017; Hur, Moon \& Ko, 2018; Sancho, Martinez, Larren \& Madueno, 2018; Zhou, Luo \& Tang, 2018; Bouraoui, Bensemmane, Ohana \& Russo, 2019). CSR communicates the underlying values of the company which can lead employees to create a strong psychological bond with the organization and afterwards generates company benefitting attitudes and behaviors (Korschun et al., 2014; Gbond, Akremi, Swaen \& Babu, 2017; Trivellas, Rafailidis, Polychroniou \& Deoulou, 2019). Accordingly, employee commitment has received much attention continuously due to its importance and the ability to impact organisations (Riketta, 2002; Bouraoui, Bensemmane, Ohana \& Russo, 2019). In today's context organisations are looking forward to have commitment from their employees continuously (Nazir \& Islam, 2017). Irrespective of using multiple methods and ways of enhancing employee commitment organisations continuously face the difficulty of maintaining a set of committed employees (Riketta, 2002; Yalabik et al., 2016; Rahman et al., 2016; Cafferkey et al., 2017; Bouraoui et al., 2019). Absence of employee commitment is detrimental to organisations. Issues related to attendance, increased labor turnover, increase in cost due to frequent recruitments and training, counterproductive behaviors (Meyer et al., 2002; Riketta, 2002; Cafferkey et al., 2017) are some of the negative outcomes due to absence of employee commitment.
Banking sector plays a major role in domestic financial sector where licensed commercial banks are the key players in it (Central Bank of Sri Lanka Annual Report, 2017). Literature also highlights that banks are experiencing lapses of commitment. Scholars such as Abdullah and Ramay (2012), Al-bdour et al. (2010), Antonaki and Trivellas (2014), Rahman et al. (2016), Shibeika (2016) have acknowledged this issue. Sri Lanka has adopted the idea of been socially responsible where almost all the organizations try to launch CSR activities as much as possible even though the real motive is questionable. The overall big picture of CSR has been researched up to a certain extent specially in terms of listed companies (Beddewala \& Fairbrass, 2014; Fernando et al., 2015; Naotunna \& Arachchige, 2016; Nimsith, Mafaza \& Safna, 2017). However, Sri Lankan banking sector and its employees' perception regarding CSR has not been examined.

Overall, employees play a major role in banking sector but adequate research has not been done to understand how employees perceive CSR practices of banks (Al-bdour, 2010). There is very limited knowledge regarding employees' perception on CSR and how they impact their attitudes and behaviors particularly in the context of developing countries (Rahman et al., 2016). On the other hand, when examining through existing scarce empirical studies, they have considered the direct relationship between CSR and other possible outcomes. Such a direct examination would not give a better understanding about the underlying mechanism as to how CSR could generate employee commitment. 'Why' such outcomes are generated questions the missing part which must be addressed (Aguinis \& Glavas, 2012; Glavas \& Kelly, 2014). Meaningful Work and Positive Affect are two of the elements of psychological well-being at work 
(Robertson \& Cooper, 2011). The necessity of focusing on psychology and their capacity to act as mediators have been overlooked (Glavas \& Kelly, 2014). Thus, based on the literature it is evident that meaningful work and positive affect have more association with CSR and employee commitment. Thus, it is hypothesized that meaningful work and positive affect explains the intermediate process between the relationship between CSR and employee commitment. Despite increased concern on psychological wellbeing at work, these variables have not been tested as potential mediators of the CSR-outcome relationships. Thus, it could be stated that coupled up with the employees' perception regarding CSR practices, these two mediators could bring an impact on employee commitment, which is tested in this study. At the same time both Social Identity Theory and Social Exchange Theory have been used to theoretically support the relationships between CSR and employee commitment (discussed in the next section).

Thus, based on the contemporary importance, dearth of studies and impact of mediators, the main objectives of this study are to, first examine the relationship between CSR perceptions and employee commitment, and then to investigate the mediating role of meaningful work and positive affect on this relationship. In terms of originality this study contributes theoretically, empirically, practically and methodologically as well. Through the examination of the said relationships the study contributes to understand whether banking employees' perception is impacted due to organization's engagement in CSR activities directed towards both internally and externally. In terms of theoretical significance, most of the studies have adopted one theory and its mostly social identity theory. This study tried to fill that gap by utilizing both social identity theory and social exchange theory so that the study is theoretically supported not by one but by two theories. While contributing empirically and theoretically its pragmatic contribution is also significant where it will be beneficial to all parties. Human resource personnel, marketers can change their view on CSR and look forward different ways of enhancing employee commitment. Particularly, the findings would be helpful for those managers who are actively involved in development of socially responsible measures for employees. Moreover, the study contributes methodologically as well. Existing literature has utilized mostly correlation analysis and regression analysis to examine relationships. But this study used Structural Equation Modelling (SEM) to examine the complex relationships accompanied with both direct and mediating relationships.

The next sections discuss the extant literature, research methods, findings and discussion and finally the conclusion of this study.

\section{Literature Review}

This section reviews broad theories and extant empirical studies relevant to the present study.

\section{Social Identity Theory}

Social Identity Theory (SIT) suggests that individuals view themselves as members of social categories such as organizational membership, religious affiliation, gender and age cohort and they compare their characteristics and the groups with other individuals and groups in order to enhance their positive self-concept (Ashforth \& Mael, 1989; Turner, 1985; Tajfel \& Turner, 1986). According to SIT, people prefer to associate with groups that permit themselves to visualize their identity in distinctive and positive manner. Brammer and Millington (2005) suggests that if employees identify their 
organization as a socially responsible member of the society, the feeling of being part of this reputable organization can enhance their self-concept. Farooq et al. (2013) and Khaleel et al. (2017) in their respective studies argue that CSR induces employees' desire to identify with their organization due to its prestigious image. Further, CSR enhances employees desire to identify them as members and it will motivate them to work and remain committed to the organization (Farooq et al., 2013). Empirical studies have also asserted that CSR creates positive reputation of an organization (Turban \& Greening, 1996; Zhou et al., 2018). Employees are proud to identify themselves with organizations that actively participate in CSR activities, which in turn improves their attitudes and behaviors in the workplace (Bouraoui et al., 2019), such as being committed employees.

\section{Social Exchange Theory}

Another broad-based theory, Social Exchange Theory suggests that signals are sent to employees that their organization is caring, kind and benevolent and the employees feel obliged to reciprocate good deeds of their company with positive attitudes and behaviors (Farooq et al., 2013). Individuals engage in different types of interactions on the basis of their assessment of potential risk and gain. Blau (1964) indicates that when individuals receive mutual benefits by interacting with a person or a group of persons and the benefits are high, they develop positive feelings towards other party. According to Social Exchange Theory this reciprocity applies where one party voluntarily provides a benefit to other party inducing an obligation to reciprocate by providing same benefit in return. This rule applies in CSR engagement where Farooq et al. (2013) argued that when firms engage in voluntary actions which are beneficial to employees and other stakeholders this reciprocity rule applies. Employees feel obliged to give something in return for these voluntary investments that was initiated towards them. CSR activities are voluntary activities carried out by the company for all types of stakeholders and it gives a signal to employees that they will be cared in the future as well. Faroog et al. (2013) suggest that employees will develop an emotional attachment and commitment towards the company as a result of receiving the feeling of been cared. Employees differentiate their level of reciprocity based on exchange ideologies "that work effort should depend on treatment by the organization" (Eisenberger et al., 1986, p. 503). Thus, employees vary their work effort based on how favorably they are treated and the benefits received from the organization. This was further elaborated by Eisenberger et al. (1986) that employees who benefit from organization will feel obliged to reciprocate by performing behaviors that benefit the organization.

Having discussed two board based theories that link between CSR perceptions and employee commitment, the next section elaborates empirical studies on this relationship.

\section{Impact of CSR on Employee Commitment}

Today, given the "circumstance of stringent scrutiny toward corporate behavior, organizations are under pressure to develop and implement solid overarching Corporate Social Responsibility (CSR) strategies" (Mory, Wirtz \& Gottel, 2016, p.172). Malik, Afzal and Mirza (2016) mention that undeniably CSR has a substantial potential to impact employees' perception about the organization. It's vital to attract a qualified pool of applicants to the organization and according to Turban and Greening (1997) good corporate social responsibility 
reputation could generate positive attention from both current and prospective employees. Commitment is the psychological identification that an individual feel toward his or her employing organization (Mowday et al., 1982). It's a relationship, genuine feeling that employees feel about their organization. High level of commitment creates benefits to both the employer and employee, and vice versa. (Bakker et al., 2003; Valentine et al., 2002).

Certain scholars were concerned about how CSR activities affect prospective employees while some others were analyzing impact towards current employees. The first stream explores how CSR actions affect prospective employees. Researches who were concerned about this area are Bhattacharya et al. (2008), Greening and Turban (2000), Turban and Greening (1997), Alniacik et al. (2011), Lin et al. (2012). These scholars found out that CSR performance is positively related to employer attractiveness only for job seekers with a high level of job choice. Careful analysis through existing line of empirical studies reveal that CSR affect current employees' attitudes and behaviors where it will lead to numerous benefits including increased job satisfaction, motivation, intention to stay, work engagement, organizational commitment, etc. Scholars such as Brammer et al. (2007), Turker (2009), ALshbiel and Awawdeh (2011), Stites and Michael (2011), Farooq et al. (2013), Ipkin and Jennifer (2014), Closan et al. (2015), Mory et al. (2016), Malik, Afzal and Mirza (2016), Engizek and Yasin (2017), Khaleel, Chelliah, Rauf and Jamil (2017), Bouraoui, Bensemmane, Ohana and Russo (2019) conducted studies to find out the link between CSR and employee commitment. When examining through the literature, it could be highlighted that scholars have examined the impact of CSR either considering only one aspect (internal or external) or both aspects of CSR. There might be a difference in the level of impact of each of the dimensions considered under CSR, but overall CSR has a positive impact on employee commitment. Accordingly, it could be hypothesized that:

H1: There is a positive relationship between CSR and Employee Commitment.

The next sections discuss the impact of the important psychological constructs: Meaningful Work and Positive Affect on the relationship between CSR perceptions and employee commitment.

\section{Meaningful Work}

Work motivation literature has been discussing the existence of a level of motivation that goes beyond the commonly known intrinsic and extrinsic motivation. One such deeper level of intrinsic motivation is meaningfulness (Chalofsky \& Krishna, 2009). Organizations perceived as socially responsible maybe sources of meaning and the authors argue that "when organisations provide their employees with opportunities to contribute something of value to fellow members of the organisational community, employees gain an enhanced sense of purpose, agency and impact which are experienced as meaningful (Rosso et al., 2010, p. 101). CSR activities may enhance members' meaningfulness of work because it corresponds to value systems of modern society, which emphasizes the economic and social needs of shareholders as well as various stakeholders (Aguinis \& Glavas, 2012).

Kim, Chang and Kim (2018) proposed that CSR functions as a key driver of employees' meaningfulness of work and the results indicated that CSR was directly and positively related to meaningfulness of work. Steger and Dik 
(2010) tested on this notion whether people who experience meaningful work are highly committed to their work both in terms of their specific organisation and their chosen profession. Results concluded employees experiencing meaningful work appear to be more satisfied and committed to their work. Jung and Yoon (2016) also examined the effects of meaningful work on employee commitment of hospitality employees. The results indicated that employees' meaning of work positively influenced their job engagement and commitment. Kim et al. (2018) also examined the impact of meaningfulness of work on organisational commitment and as per the results it clearly indicated meaningfulness of work has a significant impact on organisational commitment. Steger et al. (2012) and Khaleel et al. (2017) further emphasized that employees who experience meaningful work and who serve some greater good are better adjusted psychologically possessing qualities which are desirable to organizations. When there is meaningful work the organization will flourish with commitment, passion, imagination and soul (Richard, 1995). Literature suggests perceptions of CSR has a positive impact on meaningfulness which is followed by attitudes and behaviors desired by organisations. Thus, it could be hypothesized that:

H2a: Meaningful Work mediates the relationship between CSR and Employee Commitment.

\section{Positive Affect}

The work-place is a significant part of an employee's life which affects not only his or her life but the community as well. The work life is so important that an adult spends much of his life working (Harter et al., 2003). Emotional well-being of the employees and their satisfaction with work and work-place matters a lot. It affects the quality of an individual's life, mental health and affects the entire community. The significance of emotions has been identified and examined tremendously since the 1990s (Subba \& Rao, 2016). Positive emotions have the capability of putting down autonomic behavior of individuals whereas negative emotions cultivate autonomic behaviors (Fredrickson, 2001). Beyond just the pleasant feeling, Positive Affect generates multiple, interrelated benefits (Fredrickson \& Losada, 2005). Exposure to virtuous and socially responsible practices produces positive emotions such as love, empathy, enthusiasm, etc. (Cameron, Mora \& Calarco, 2011). Individuals working in socially responsible organizations find their job more intrinsically rewarding, and leads to greater positive affect (Ryan \& Deci, 2000; Lyubomirsky, King \& Diener, 2005). According to the study conducted by Baranik and Eby (2016) their conclusion was that organisational citizenship behaviors were related to positive affect and positive affect was positively related to life satisfaction and health satisfaction and negatively related to burnout and depressed mood. As per literature it could be hypothesized that:

H2b: Positive Affect mediates the relationship between CSR and Employee Commitment

Based on literature review the conceptual framework was constructed in figure 01 (Appendix A).

\section{Methodology}

Based on philosophical assumptions, the study falls under positivistic paradigm. Since the study examines relationships between variables, quantitative strategy was utilized. The population constitutes of licensed commercial banking sector of Sri Lanka. Data was collected from a sample of 13 domestic licensed commercial banks in Sri Lanka. Data collection was facilitated using 
convenience sampling strategy due to non-availability of the sampling frame.

\section{Operationalization}

\section{Measurement scales}

CSR Engagement: Banks conduct CSR activities towards multi stakeholders. Employees' current perception of its bank's CSR activities is examined under CSR engagement. Turker's (2009) CSR definition was considered as the base which considered CSR as "those corporate behaviors which affect stakeholders positively and goes beyond its economic interests and legal obligations" (p. 201). Turker (2009) identified only four stakeholder types. In this research CSR engagement was measured incorporating multi stakeholder items along with Turker's (2009) classification. CSR engagement was measured using employees, social and non-social stakeholders, customers, government and shareholders. A combination of scales was used since these stakeholders are not covered from a single scale. Scholars have used Turker's scale to measure CSR involvement which covers wide range of stakeholders (Farooq et al., 2013; Nejati \& Ghasemi, 2013; Chaudhary, 2017). Thus, Turker's (2009) seventeen items CSR scale was adapted to measure level of CSR engagement towards employees, social and non-social stakeholders, customers and government (e.g. our bank encourages its employees to participate in voluntary activities, our bank participates in activities which aim to protect and improve the quality of the natural environment, our bank makes investment to create a better life for future generations, customer satisfaction is highly important for our bank, our bank always pays its taxes on a regular and continuing basis) Also, to measure level of CSR engagement towards shareholders three statements were utilized from Fatma et al. (2014), Garcia et al. (2005) and
Maignan and Ferrell (2001). "Our bank tries to obtain maximum profit from its activity", "our bank keeps strict control over its cost", and "our bank is concerned to fulfill its obligations in relation to its shareholders". The term "company" was changed to "our bank" in order to suit the context. The Original five (5) point Likert type scale ranging from strongly disagree $=1$ to strongly agree $=5$ was used in the questionnaire.

Employee Commitment: The researchers used the 9 item short version of Organisational Commitment Questionnaire (Mowday, Steers \& Porter, 1979) to measure current level of employee commitment where the short version is reliable same as the original 15 items scale (Mowday, Steers \& Porter, 1979; Turker, 2009). The scale included affective, normative and continuous components of commitment (e.g. I find that my values and the bank's values are very similar, I am willing to put in a great deal of effort beyond that normally expected in order to help this bank be successful, for me this is the best of all possible banks for which to work). Original seven (7) point Likert type scale ranging from strongly disagree $=1$ to strongly agree $=7$ was incorporated to measure the scale. Also, the original word "organization" was changed to "bank" in order to suit the context of the research.

Meaningful Work: The researchers adopted the Comprehensive Meaningful Work Scale (Wiersma \& Wright, 2012) to measure meaningful work with modifications based on expert comments and pilot-survey results. Scholars have adopted this scale to measure meaningful work in their research (Vuori, San \& Kira, 2012; Wiersma, Wright \& Dik, 2016) since this scale covers several dimensions and developed by combining a number of existing scales. Originally this scale comprised of twenty-eight items covering seven dimensions. In terms of the study, two items from each dimension totaling 
of fourteen items were selected to measure level of meaningful work (e.g. I have a sense of belonging, I feel I truly help our customers/ clients, I create and apply new ideas or concepts, I feel inspired at work). Respondents were informed to indicate their preference with regard to how frequently they experienced each item at their bank. Based on the original scale, a five-point Likert type scale ranging from never $=1$ to always $=5$ was used to measure the scale.

Positive Affect: Thompson (2007) mentions that the original PANAS scale is criticized for been lengthy when used in a study which involves other set of variables also. Further Thompson (2007) mentions that psychometric properties of the new ten items have been tested and validated which covers both positive and negative affect. Thus, researchers used modified PANAS (I-PANAS) developed by Thompson (2007) to measure positive affect. Items which measured positive affect are alert, determined, attentive, active, inspired. The researchers used these five (5) items (e.g. alert, determined, attentive, active, inspired) to measure Positive Affect and the original five (5) point Likert type scale ranging from very slightly or not at all $=1$ to extremely $=5$ was used to measure the levels.

\section{Data Collection and Demographic Profile}

This study focusses on the level of CSR engagement of the Licensed Commercial Banking sector of Sri Lanka. Currently 25 domestic and foreign Licensed Commercial Banks (LCBs) are operating in Sri Lanka (Central Bank of Sri Lanka Annual Report, 2016).

For this study purpose, the researchers selected both executive and nonexecutive employees of 13 domestic LCBs. Researchers managed to collect
415 filled questionnaires, but, only 410 were usable for data analysis.

Majority of the respondents were females which accounted to $55.6 \%$. In terms of Marital Status of the respondents, majority of the respondents were married $(72.7 \%)$. Regarding the age distribution of sample respondents, it is observed that two age groups: $31-40$ and 21-30 had representations of $35.4 \%$ and $31.2 \%$, respectively. When academic qualifications are concerned, it could be seen that the majority participants fell under who had completed their First degrees (29.8\%). However, percentage of Masters/ M.Phil. levels completed is also at a higher level demonstrating a percentage of $24.7 \%$. $43.9 \%$ of the respondents held Associateship in Banking (AIB) which is a common feature in banks, and $27.1 \%$ are still in the process of completing AIB. Out of the employment categories of clerical, junior executive, executive and assistant managers, the highest percentage of $19.3 \%$ was represented by the junior executive category.

Also, when considered the high end of the employment categories, senior manager and assistant general manager categories held the highest percentages of $7.8 \%$ and $7.1 \%$, respectively. With regard to total service length at the banks, the highest percentage is held by 'more than 5 years but not over 10 years' category (25\%). It is followed by $20 \%$ which represent 'more than 10 years but not over 15 years' tenure category. As far as monthly gross salary is concerned, the highest percentage of the respondents $(26.1 \%)$ earned a salary between Rs. 75,001100,000 . Closer to this figure $20.2 \%$ of the respondents earned a salary between Rs. 50,001-75,000.

\section{Analysis strategy}

In terms of data analysis, first, the data was subjected to screening and cleaning. 
Then, validity and reliability dimensions were examined. In order to describe the sample, descriptive statistics accompanied by measures of central tendency, measures of dispersion and measures of distribution were calculated using statistical analysis package - SPSS. Further, to examine the hypothesized relationships, correlation analysis and structural equation modeling (i.e., using Smart Partial Least Square (PLS) software) were conducted being deemed most appropriate strategies. The use of PLS for this study is relevant due to several reasons. Firstly, this study examined complex relationships. i.e. two mediation relationships along with direct relationships which in overall is a complex model. The prime objective is to predict, i.e. the purpose of this study is to explore the impact, the relationships between CSR and employee commitment with the mediating effects of Meaningful Work and Positive Affect, and these complex relationships including direct relationships, mediation and moderations could be tested using Structural Equation Modeling (SEM). Further, tests of normality, indicated (not tabulated) that the distribution of data is non-normal, which violates one of the multivariate assumptions of covariates-based general SEM, and thus, the use of PLS is appropriate in such a situation as it is not based on covariate-based SEM (Hair et al., 2014; Garson, 2016). Further, the proposed conceptual model comprises constructs with large number of indicators, complex relationships where use of PLS is recommended to explore such a context (Fornell \& Cha, 1994). Nevertheless, expert statisticians' opinions were obtained in order to confirm suitability of using SEM. Thus, above given reasons justify use of PLS for data analysis in this study.

SEM techniques such as PLS establish a correctly the specified measurement model before evaluating the structural (theoretical) model. Model specification includes two distinct components (a) a measurement model and (b) a structural model (Hair et al., 2014; Samani, 2016). Accordingly, in this study, under the measurement model, a confirmatory factor analysis was used to validate the items (indicators) explicitly measuring the individual latent variables. Where-as the structural model takes in to account the relationships among the latent variables to be estimated and tested (Garson, 2016). Content validity, convergent validity (Composite Reliability \& Cronbach's Alpha) and discriminant validity were examined in both measurement model and the structural model.

\section{Findings \& Discussion}

Before testing hypotheses of this study, convergent validity and discriminant validity of the structural model were tested.

Convergent validity was assessed using composite reliability, Cronbach's Alpha and AVE which are the commonly used validation measurements. As per the results indicated in Table 01 (Appendix B), the composite reliability and Cronbach's Alpha is well above 0.7 of all variables, which is the accepted threshold. Thus, due to adequate satisfaction of composite reliability and Cronbach's Alpha convergent validity is ensured. Moreover, to establish convergent validity AVE values were also examined. The accepted norm is AVE should be greater than 0.5 which means factors should explain at least half the variance of their respective indicators. AVE below 0.5 means error variance exceeds explained variance. As per Table 1 , all variables' AVE values meet the acceptable criterion. Discriminant validity is achieved if an item correlates more highly with items measuring the same construct than with items measuring different constructs (Churchill, 1979). 
Discriminant validity was assessed using the Fornell and Larcker (1981) AVE criterion. Discriminant validity is supported by the results of Table 02 (Appendix C), the inter-construct correlations table. The square root of AVE which is represented in the diagonal is higher than its column wise and row wise correlation for all the variables.

\section{Hypotheses testing}

Related to Hypothesis (H1): CSR positively impacts employee commitment, the path coefficient is 0.623 (Table 03 - Appendix D), which is also significant $(\mathrm{p}<0.01)$. Thus, based on this information, hypotheses $\mathrm{H} 1$ is supported indicating positive relationship between CSR and employee commitment.

Related to hypothesis (H2a): Meaningful Work mediates the relationship between CSR and employee commitment, all the direct paths (CSR and employee commitment, CSR and meaningful work, meaningful work and employee commitment) as indicated in Table 04 (Appendix E) are statistically significant. The indirect path between CSR and employee commitment is also significant. Hence, it could be concluded that hypothesis $\mathrm{H} 2 \mathrm{a}$ is supported since both direct and indirect paths are significant indicating meaningful work partially mediates the relationship between CSR and employee commitment.

As per hypothesis H2b: Positive affect mediates the relationship between CSR and employee commitment, all three direct paths as indicated in Table 05 (Appendix F), are statistically significant. In order to examine mediation effect of positive affect both direct and indirect paths have to be considered. Along with the direct path the indirect path between CSR to employee commitment is also significant. Thus, hypothesis $\mathrm{H} 2 \mathrm{~b}$ is supported concluding that positive affect partially mediates the relationship between CSR and employee commitment. Figure 02 (Appendix G) indicates the final path diagram of the relationships examined.

\section{Conclusion}

The main findings of this study could be elaborated in relation to research objectives, and the first objective of this was to investigate the level of CSR engagement and employee commitment in licensed commercial banks. As per the results, commercial banks' level of CSR engagement was at a higher level, which indicated a value of 4.19 out of 5 . Also, employees of commercial banks exhibited a higher level of commitment at work as well. The value indicated was 6.05 out of 7 .

Then the study investigated the impact of CSR on employee commitment as the second main objective of this study. As per the results, it was found that there is a positive relationship between CSR engagement and employee commitment. This result supports the findings of previous empirical findings that employees' perception about their organisation's level of CSR engagement has a significant positive impact on their level of commitment (Turker, 2009; Farooq et al., 2013; Closan et al., 2015). Employees get a positive perception about their organisation when their organisation engages in CSR activities, i.e. higher the organisations engage on CSR activities, higher the level of employees' commitment. This suggests that organisations which embrace CSR activities targeting both internal and external stakeholders as part of their strategy more successfully gain the commitment of their employees.

The third objective of the study was to examine the mediating effects of meaningful work and positive affect on the impact of CSR on employee commitment. The results depicted that 
employees' perception of CSR engagement of their organisation not only directly influence employee commitment but also impact through meaningful work as well. This imply that employees consider working for a socially responsible organisation creates a meaningful purpose to retain with the organisation which in turn trigger higher level of commitment. Moreover, the results showed that a positive relationship exists between CSR engagement and positive affect. This finding is in par with the notion that when employees are exposed to virtuous and socially responsible practices they tend to develop positive emotions which in turn generates positive benefits. Further, the results confirmed that employees' perception of CSR engagement of their organisation not only directly influence employee commitment but also impacts through positive affect, i.e. positive affect could mediate the relationship between CSR and employee commitment.

\section{Implications}

The results of this research contributes theoretically, empirically, pragmatically and methodologically as follows.

\section{Theoretical implications}

The review of literature indicated that most of the studies have primarily focused on Social Identity Theory (SIT) when examining the relationships between CSR and possible outcomes. This study also utilized the Social Exchange Theory (SET) as an additional and complementary theory to support this relationship. Thus, the relationships between CSR, employee commitment, meaningful work and positive affect are better explained due to usage of both SIT and SET, and the findings support these theories.

\section{Empirical implications}

The study examined the direct impact of CSR engagement on employee commitment. The findings of this study further enrich existing literature on the impact of CSR at micro level highlighting the employees' perception on CSR leads to higher level of commitment. More importantly, this study's finding would enrich existing few empirical studies available in the Sri Lankan banking context opening up new path for future researchers.

\section{Practical implications}

This study attempts to shed new light on CSR at a micro level. findings would give better understanding as to how stakeholders would respond to CSR activities, specially the employees. Since studies concerning on micro CSR is limited in developing countries organisations are losing potential benefits. This study's findings also indicate that employees do pay attention on the organisation's CSR activities. Their perception regarding the organisation is largely impacted by the level of CSR engagement of their organisation. Managers should understand the importance of including CSR activities into their strategy if they look forward to survive and thrive. Human resource and marketing managers must understand the value that could be generated through CSR activities. Being a socially responsible organisation would attract prospective employees and would help to retain talented employees. Thus, findings of this study would be useful for managers who are actively involved in developing CSR practices.

\section{Methodological implications}

The conceptual framework of this study included a combination of independent, dependent and mediating variables. To test the hypotheses of this study structural equation modelling was utilized. Use of structural equation modelling to test 
hypotheses of complex models is still underutilized in CSR literature. Apart from the main direct relationships, two mediators (i.e., Meaningful Work and Positive Affect) were also tested using structural equation modelling. These improvements are expected to contribute methodologically.

\section{Limitations and future research directions}

This study has contributed to CSR literature in many ways. However, it exhibits a few limitations where the researchers suggest them as future research directions. The study examined licensed commercial banking sector. To obtain an overall understanding of the total banking sector, future research could consider savings and development banking sectors as well. Furthermore, as a future direction, employees' perception of CSR could be examined in other sectors as well. This study examined both internal and external CSR activities representing different types of key stakeholders which included social and non-social stakeholders (natural environment, society, NGOs), employees, customers, government, and shareholders. More insights could have been gained if some other stakeholders such as suppliers were also included. As future research directions, other such stakeholders could be considered. There is an increased concern on emotions where psychological foundations of CSR could be a lucrative mediation mechanism. Thus, more psychologically related variables could be used as mediators in future research. In addition, justice mechanisms could also be considered as mediators for future research.

\section{References}

Abdullah, \& Ramay, M. I. (2012). Antecedents of Organizational Commitment: A Study of Banking Sector of Pakistan. Serbian Journal of Management, 7 (1), 89-102.

Aguinis, H., \& Glavas, A. (2012). What we know and don't know about corporate social responsibility: A review and research agenda. Journal of Management, 38, 932-68.

Al-bdour, A. A., Nasruddin, E., \& Lin, S. K. (2010). The relationship between internal corporate social responsibility and organizational commitment within the banking sector in Jordan. International Journal of Human and Social Sciences, 5(14), 932-951.

Alniacik, U., Alniacik, E., \& Genc, N. (2011). How corporate social responsibility information influences stakeholders' intentions. Corporate Social Responsibility and Environmental Management, 18(4), 234-245.

ALshbiel, S. O., \& Al-Awawdeh, W. M. (2011). Internal social responsibility and its impact on job commitment: Empirical study on Jordanian cement manufacturing company. International Journal of Business and Management, 6(12), 94102.

Antonaki, X. E., \& Trivellas, P. (2014). Psychological contract breach and organizational commitment in the Greek banking sector: The mediation effect of job satisfaction. Procedia-Social and Behavioral Sciences, 148(1), 354-361.

Ashforth, B. E., \& Mael, F. (1989). Social identity theory and the organization. Academy of Management Review, 14(1), 20-39.

Bakker, A. B., Demerouti, E., De Boer, E., \& Schaufeli, W. B. (2003). Job demands and job resources as predictors of absence duration and frequency. Journal of Vocational Behavior, 62(2), 341-356. 
Baranik, L. E., \& Eby, L. (2016). Organizational citizenship behaviors and employee depressed mood, burnout, and satisfaction with health and life: The mediating role of positive affect. Personnel Review, 45(4), 626-642.

Beddewela, E., \& Fairbrass, J. (2015). Seeking legitimacy through CSR: Institutional pressures and corporate responses of multinationals in Sri Lanka. Journal of Business Ethics, 136(3), 503522.

Bhattacharya, C. B., Sen, S., \& Korschun, D. (2008). Using corporate social responsibility to win the war for talent. MIT Sloan Management Review, 49(2), 37-44.

Blau, P. (1964). Exchange and Power in Social Life. New York: Wiley.

Bouraoui, K., Bensemmane, S., Ohana, M., \& Russo, M. (2019). Corporate social responsibility and employees' affective commitment: A multiple mediation model. Management Decision, 57(1), 152-167.

Brammer, S., \& Millington, A. (2005). Corporate reputation and philanthropy: An empirical analysis. Journal of Business Ethics, 61(1), 29-44.

Brammer, S., Williams, G., \& Zinkin, J. (2007). Religion and attitudes to corporate social responsibility in a large cross-country sample. Journal of Business Ethics, 71(3), 229-243.

Cafferkey, K., Harney, B., Dundon, T., \& Edgar, F. (2017). Unravelling the foci of employee commitment. Journal of Organizational Effectiveness: People and Performance, 4(1), 2-17.

Cameron, K., Mora, C., Leutscher, T., \& Calarco, M. (2011). Effects of positive practices on organizational effectiveness.
The Journal of Applied Behavioral Science, 47(3), 266-308.

Central Bank Report, (2016). Retrieved from

https://www.cbsl.gov.lk/en/publications/ economic-and-financial-reports/annualreports/annual-report-2016, (Accessed 20 July 2019).

Central Bank Report, (2017). Retrieved from

https://www.cbsl.gov.lk/en/publications/ economic-and-financial-reports/annualreports/annual-report-2017, (Accessed 20 July 2019).

Chalofsky, N., \& Krishna, V. (2009). Meaningfulness, commitment, and engagement: The intersection of a deeper level of intrinsic motivation. Advances in Developing Human Resources, 11(2), 189-203.

Chaudhary, R. (2017). Corporate social responsibility and employee engagement: can CSR help in redressing the engagement gap? Social Responsibility Journal, 13(2), 323-338.

Churchill, G. A., Jr. (1979). A paradigm for developing better measures of marketing constructs. Journal of Marketing Research, 16(1), 64-73.

Closan, C., Leys, C., \& Hellemans, C. (2015). Perceptions of corporate social responsibility, organizational commitment and job satisfaction. Management Research: The Journal of the Iberoamerican Academy of Management, 13(1), 31-54.

Eisenberger, R., Huntington, R., Hutchison, S., \& Sowa, D. (1986). Perceived organizational support. Journal of Applied Psychology, 71(1), 500-507.

Engizek, N., \& Yasin, B. (2017). How CSR and overall service quality lead to 
affective commitment: mediating role of company reputation. Social Responsibility Journal, 13(1), 111-125.

Farooq, O., Payaud, M., Merunka, D., \& Valette-Florence, P. (2013). The impact of corporate social responsibility on organizational commitment: Exploring multiple mediation mechanisms. Journal of Business Ethics, 125(4), 563-580.

Fatma, M., Rahman, Z., \& Khan, I. (2014). Multi-Item Stakeholder Based Scale to Measure CSR in the Banking Industry. International Strategic Management Review, 2(1), 9-20.

Fernando, S., Lawrence, S., Kelly, M., \& Arunachalam, M. (2015). CSR practices in Sri Lanka: an exploratory analysis. Social Responsibility Journal, 11(4), 868892.

Fornell, C., \& Cha, J. (1994). Partial least squares. In R. P. Bagozzi (Eds.), Advanced Methods in Marketing Research (pp. 52-78). Malden, MA: Blackwell Publishers.

Fornell, C., \& Larcker, D. F. (1981). Evaluating structural equation models with unobservable variables and measurement error. Journal of Marketing Research, 18(1), 39-50.

Fredrickson, B. L. (2001). The role of positive emotions in positive psychology: The broaden-and-build theory of positive emotions. American Psychologist, 56(3), 218-226.

Fredrickson, B. L., \& Losada, M. F. (2005). Positive affect and the complex dynamics of human flourishing. American Psychologist, 60(7), 678-686.

Garcia de los Salmones, M. M., Herrero, A., \& Del Bosque, I. R. (2005). Influence of corporate social responsibility on loyalty and valuation of services. Journal of Business Ethics, 61(4), 369-385.
Garson, D. (2016). Partial Least Squares (PLS-SEM): Regression and Structural Equation Models. North Carolina: Statistical Publishing Associates.

Glavas, A., \& Kelley, K. (2014). The effects of perceived corporate social responsibility on employee attitudes. Business Ethics Quarterly, 24(2), 165202.

Gond, J. P., El Akremi, A., Swaen, V., \& Babu, N. (2017). The psychological micro foundations of corporate social responsibility: A person-centric systematic review. Journal of Organizational Behavior, (2), 225-246.

Greening, D. W., \& Turban, D. B. (2000). Corporate social performance as a competitive advantage in attracting a quality workforce. Business \& Society, 39(3), 254-280.

Hair Jr, J. F., Hult, G. T. M., Ringle, C., \& Sarstedt, M. (2014). A Primer on Partial Least Squares Structural Equation Modeling (PLS-SEM). CA: Sage Publications.

Harter, J.K., Schmidt, F.L., \& Keyes, C.L. (2003). Well-Being in the Workplace and its Relationship to Business Outcomes: A Review of the Gallup Studies. In C.L. Keyes \& J. Haidt (Eds.), Flourishing: The Positive Person and the Good Life (pp. 205-224). Washington D.C.: American Psychological Association. https://psycnet.apa.org/doi/10.1037/1059 4-009.

Hur, W. M., Moon, T. W., \& Ko, S. H. (2018). How employees' perceptions of CSR increase employee creativity: Mediating mechanisms of compassion at work and intrinsic motivation. Journal of Business Ethics, 153(3), 629-644.

Ipkin, A. W., \& Jennifer, H. G. (2014). Exploring the direct and indirect effects 
of CSR on organizational commitment. International Journal of Contemporary Hospitality Management, 26(4), 500-525.

Jung, H. S., \& Yoon, H. H. (2016). What does work meaning to hospitality employees? The effects of meaningful work on employees' organizational commitment: The mediating role of job engagement. International Journal of Hospitality Management, 53, 59-68.

Khaleel, M., Chelliah, S., Rauf, S., \& Jamil, M. (2017). Impact of perceived corporate social responsibility on attitudes and behaviors of pharmacists working in MNCs. Humanomics, 33(4), 453-469.

Kim, B. J., Chang, Y. K., \& Kim, T. H. (2018). How Does Corporate Social Responsibility Promote Innovation? The Sequential Mediating Mechanism of Employees' Meaningfulness of Work and Intrinsic Motivation. In Proceedings of the International Conference on System Sciences, 51 (pp. 104-113). Hawaii.

Korschun, D., Bhattacharya, C. B., \& Swain, S. D. (2014). Corporate social responsibility, customer orientation, and the job performance of frontline employees. Journal of Marketing, 78(3), 20-37.

Lechuga Sancho, M. P., MartínezMartínez, D., Larran Jorge, M., \& Herrera Madueno, J. (2018). Understanding the link between socially responsible human resource management and competitive performance in SMEs. Personnel Review, 47(6), 1211-1243.

Lin, C. P., Baruch, Y., \& Shih, W. C. (2012). Corporate social responsibility and team performance: The mediating role of team efficacy and team selfesteem. Journal of Business Ethics, 108(2), 167-180.
Lips-Wiersma, M., \& Wright, S. (2012). Measuring the meaning of meaningful work: Development and validation of the comprehensive meaningful work scale (CMWS). Group \& Organization Management, 37(5), 655-685.

Lips-Wiersma, M., Wright, S., \& Dik, B. (2016). Meaningful work: differences among blue-, pink-, and white-collar occupations. Career Development International, 21(5), 534-551.

Lyubomirsky, S., King, L., \& Diener, E. (2005). The benefits of frequent positive affect: Does happiness lead to success? Psychological Bulletin, 131(6), 803-855. https://psycnet.apa.org/doi/10.1037/0033 -2909.131.6.803.

Maignan, I., \& Ferrell, O. C. (2001). Corporate citizenship as a marketing Instrument-Concepts, evidence and research directions. European Journal of Marketing, 35(3), 457-484.

Malik, W. U., Afzal, Q., \& Mirza, H. U. (2016). A Source of Employee Inspiration through perceived Corporate Social Responsibility, Motivation \& Commitment: Evidence from NGO Sector of Pakistan. International Journal of Academic Research in Business and Social Sciences, 6(2), 57-79.

Mory, L., Wirtz, B. W., \& Göttel, V. (2016). Factors of internal corporate social responsibility and the effect on organizational commitment. The International Journal of Human Resource Management, 27(13), 13931425.

Mowday, R. T., Porter, L. W., \& Steers, R. M. (1982). Employee-organization linkages: The Psychology of Commitment, Absenteeism, and Turnover. New York: Academic Press.

Mowday, R. T., Steers, R. M., \& Porter, L. W. (1979). The measurement of 
organizational commitment. Journal of Vocational Behavior, 14(2), 224-247.

Naotunna, S., \& Arachchige, B. (2016). Perceived Organizational Support and Non-Managerial Employees' Commitment to Change in Sri Lankan Apparel Firms. South Asian Journal of Human Resources Management, 3(1), 4057.

Nazir, O., \& Islam, J. U. (2017). Enhancing organizational commitment and employee performance through employee engagement: An empirical check. South Asian Journal of Business Studies, 6(1), 98-114.

Nejati, M., \& Ghasemi, S. (2013). Corporate social responsibility and organizational commitment: Empirical findings from a developing country. Journal of Global Responsibility, 4(2), 263-275.

Nimsith, S. I., Mafaza, M. H. F., \& Safna, H. M. F. (2017). Effect of corporate social responsibility on financial performance of banks in Sri Lanka. In Proceedings of South Eastern University of Arts (pp. 12-24). Sri Lanka. http://ir.lib.seu.ac.lk/handle/123456789/ 2187.

Rahman, S., Haski-Leventhal, D., \& Pournader, M. (2016). The effect of employee CSR attitudes on job satisfaction and organizational commitment: evidence from the Bangladeshi banking industry. Social Responsibility Journal, 12(2), 228-246.

Richards, D. (1995). Artful work: Awakening joy, meaning, and commitment in the workplace. San Francisco: Berrett-Koehler.

Riketta, M. (2002). Attitudinal organizational commitment and job performance: a meta-analysis. Journal of
Organizational Behavior, 23(3), 257266.

Robertson, I., \& Cooper, C. (2011). Wellbeing: Productivity and happiness at work. London: Palgrave Macmillan. https://doi.org/10.1057/9780230306738

Rosso, B. D., Dekas, K. H., \& Wrzesniewski, A. (2010). On the meaning of work: A theoretical integration and review. Research in Organizational Behavior, 30, 91-127.

Ryan, R. M., \& Deci, E. L. (2000). Intrinsic and extrinsic motivations: Classic definitions and new directions. Contemporary Educational Psychology, 25(1), 54-67.

Samani, S.H. (2016). Steps in partial least square of structural equation modelling (PLS-SEM). International Journal of Social Sciences and Business, 1(2), 5566.

Shibeika, A. M. (2016). The Impact of Job Satisfaction on Facet of Organizational Commitment (Affective, Continuance and Normative Commitment): A Study of Banking Sector Employees of Sudan. International Journal of Human Resources Development and Management, 2(5), 2395-4396.

Steger, M. F., \& Dik, B. J. (2010). Work as meaning: Individual and organizational benefits of engaging in meaningful work. In Oxford Handbook of Positive Psychology and Work (pp. 131142). Oxford UK: Oxford University Press.

Steger, M. F., Dik, B. J., \& Duffy, R. D. (2012). Measuring meaningful work: The work and meaning inventory (WAMI). Journal of Career Assessment, 20(3), 322-337. 
Stites, J. P., \& Michael, J. H. (2011). Organizational commitment in manufacturing employees: Relationships with corporate social performance. Business \& Society, 50(1), 50-70.

Subba, D., \& Rao, M. K. (2016). Measuring the Effects of CSR on Compassion at Workplace: An Empirical Study in North East Region of India. Journal of Management Ethics and Spirituality, 9(1), 25-42.

Tajfel, H., \& Turner, J. C. (1986). The social identity theory of intergroup behavior', In S. Austin and W.G. Austin (Eds.), Psychology of Intergroup Relations (pp. 7-24). Chicago: Nelson Hall.

Thompson, E. R. (2007). Development and validation of an internationally reliable short-form of the positive and negative affect schedule (PANAS). Journal of Cross-Cultural Psychology, 38(2), 227-242.

Trivellas, P., Rafailidis, A., Polychroniou, P., \& Dekoulou, P. (2019). Corporate social responsibility (CSR) and its internal consequences on job performance. International Journal of Quality and Service Sciences, 11(2), 265282.

Turban, D. B., \& Greening, D. W. (1997). Corporate social performance and organizational attractiveness to prospective employees. Academy of Management Journal, 40(3), 658-672.

Turker, D. (2009). How corporate social responsibility influences organizational commitment. Journal of Business Ethics, 89(2), 189-204.

https://doi.org/10.1007/s10551-008-

9993-8.

Turker, D. (2009). Measuring corporate social responsibility: A scale development study. Journal of Business Ethics, 85(4), 411-427.

Turner, J. C. (1985). Social categorization and the self-concept: A social cognitive theory of group behavior. Advances in group processes: Theory and research, 2 , 77-122.

Valentine, S., Godkin, L., \& Lucero, M. (2002). Ethical context, organizational commitment, and person-organization fit. Journal of Business Ethics, 41(4), 349360.

Vuori, T., San, E., \& Kira, M. (2012). Meaningfulness-making at work. Qualitative Research in Organizations and Management: An International Journal, 7(2), 231-248.

Yalabik, Z. Y., Swart, J., Kinnie, N., \& Van Rossenberg, Y. (2017). Multiple foci of commitment and intention to quit in knowledge-intensive organizations (KIOs): what makes professionals leave? The International Journal of Human Resource Management, 28(2), 417-447. https://doi.org/10.1080/09585192.2016.1 244918.

Zhou, Z., Luo, B. N., \& Tang, T. L. P. (2018). Corporate social responsibility excites 'exponential' positive employee engagement: The Matthew effect in CSR and sustainable policy. Corporate Social Responsibility and Environmental Management, 25(4), 339-354. 


\section{Appendices}

\section{Appendix A}

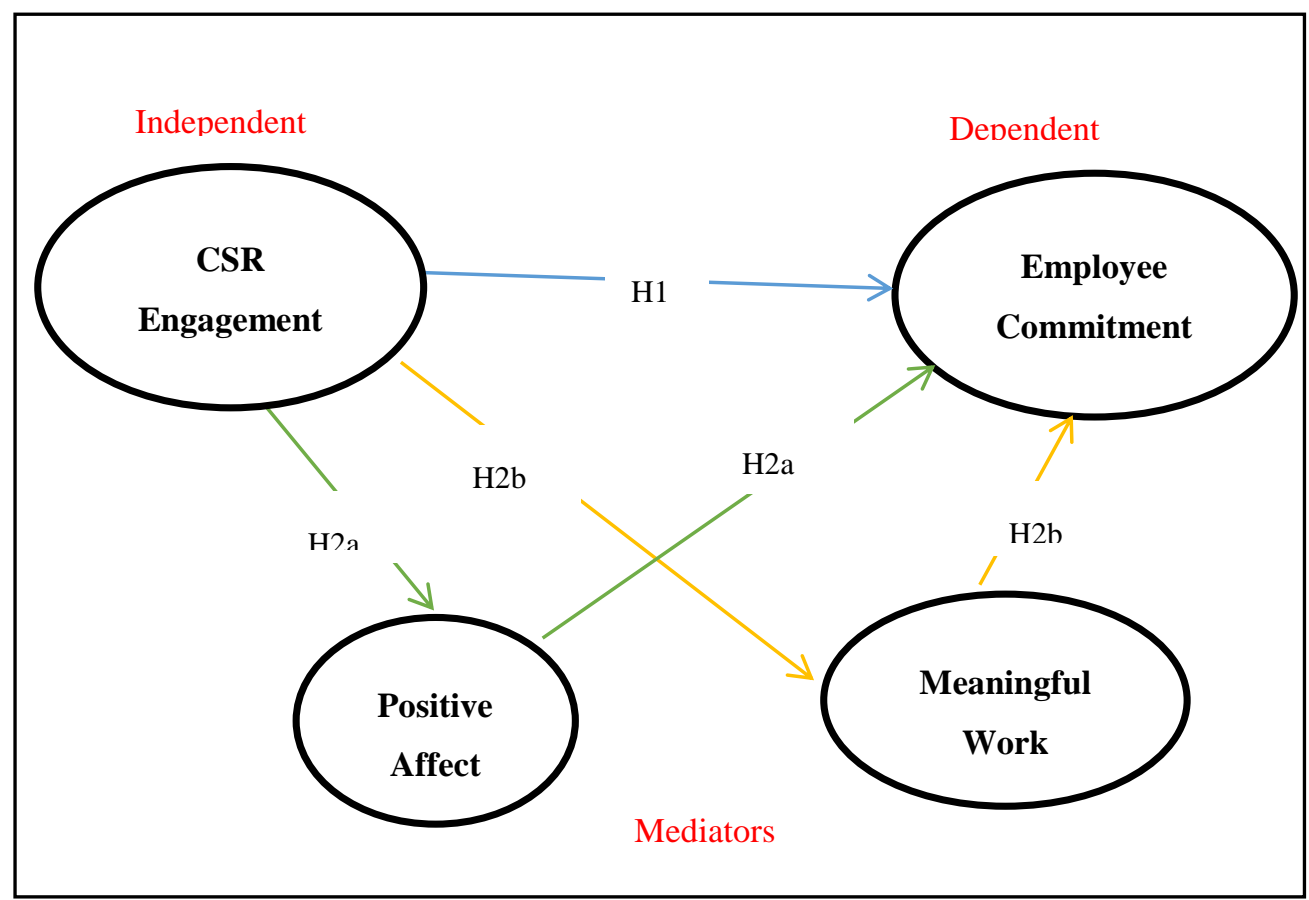

Figure 01: Conceptual framework

Source: Authors constructed

\section{Appendix B}

Table 1: Summary of convergent validity

\begin{tabular}{|c|c|c|c|}
\hline $\begin{array}{l}\text { Construct/ } \\
\text { dimension }\end{array}$ & AVE & $\begin{array}{l}\text { Composite } \\
\text { Reliability }\end{array}$ & Cronbach's Alpha \\
\hline CSR-CSR & 0.668 & 0.909 & 0.875 \\
\hline $\begin{array}{l}\text { Engagement } \\
\text { EC-Employee }\end{array}$ & 0.593 & 0.928 & 0.912 \\
\hline Commitment & & & \\
\hline $\begin{array}{l}\text { MW- Meaningful } \\
\text { Work }\end{array}$ & 0.595 & 0.870 & 0.825 \\
\hline PA- Positive Affect & 0.689 & 0.917 & 0.886 \\
\hline
\end{tabular}

Source: Authors compiled based on analysis 
Weerasekara N., Ajward R., KJM, 2020, 09 (01)

\section{Appendix C}

Table 2: Inter-construct correlation table

\begin{tabular}{lcccc}
\hline & CSR & EC & MW & PA \\
\hline CSR & $\mathbf{0 . 8 1 7}$ & & & \\
EC & 0.623 & $\mathbf{0 . 7 7 0}$ & & \\
MW & 0.458 & 0.438 & $\mathbf{0 . 7 0 4}$ & \\
PA & 0.505 & 0.480 & 0.491 & $\mathbf{0 . 8 3 0}$ \\
\hline
\end{tabular}

Source: Authors compiled based on analysis

\section{Appendix D}

Table 3: Direct impact of CSR on Employee Commitment

\begin{tabular}{lccc}
\hline Path & Path coefficient & t-statistic & p-value \\
\hline $\mathrm{CSR} \rightarrow$ EC & 0.623 & 16.115 & 0.000 \\
\hline
\end{tabular}

Source: Authors compiled based on analysis

\section{Appendix E}

Table 4: Mediating effect of Meaningful work

\begin{tabular}{lcccc}
\hline Path & $\begin{array}{c}\text { Path } \\
\text { coefficient }\end{array}$ & t-statistic & p-value & $\begin{array}{c}\text { Total } \\
\text { effect }\end{array}$ \\
\hline CSR $\rightarrow$ EC (Direct) & 0.623 & 16.115 & 0.000 & 0.712 \\
CSR $\rightarrow$ EC (Indirect) & & 3.285 & 0.001 & \\
CSR $\rightarrow$ MW & 0.458 & 10.176 & 0.000 & \\
MW $\rightarrow$ EC & 0.195 & 3.433 & 0.001 & \\
\hline
\end{tabular}

Source: Authors compiled based on analysis

\section{Appendix F}

Table 5: Mediating effect of Positive Affect

\begin{tabular}{lllll}
\hline Path & Path coefficient & t-statistic & p-value & $\begin{array}{c}\text { Total } \\
\text { effect }\end{array}$ \\
\hline CSR $\rightarrow$ EC (Direct) & 0.623 & 16.115 & 0.000 & 0.735 \\
CSR $\rightarrow$ EC (Indirect) & & 3.959 & 0.000 & \\
CSR $\rightarrow$ PA & 0.504 & 10.836 & 0.000 & \\
PA $\rightarrow$ EC & 0.222 & 4.359 & 0.000 & \\
\hline
\end{tabular}

Source: Authors compiled based on analysis 
Weerasekara N., Ajward R., KJM, 2020, 09 (01)

\section{Appendix G}

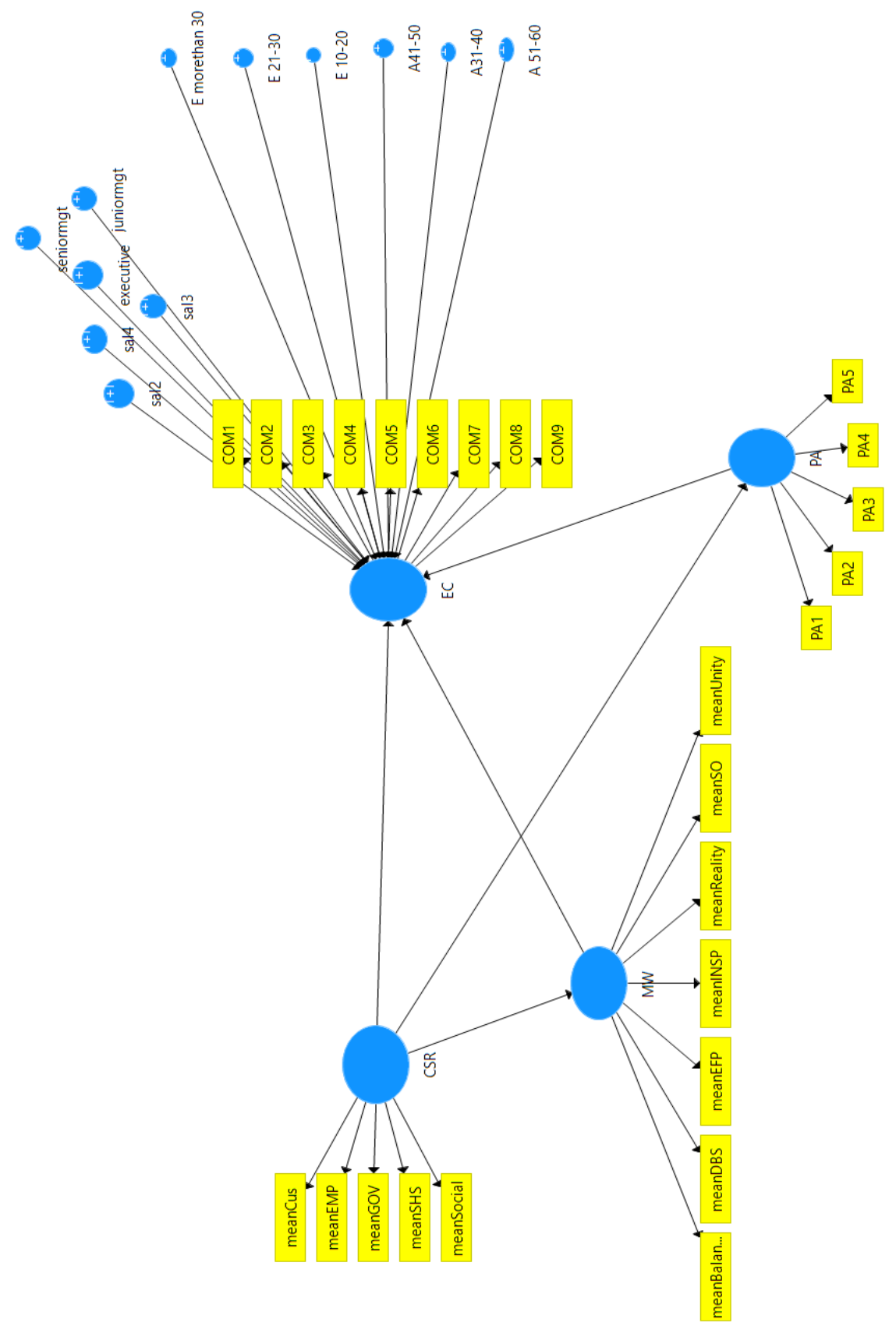

Figure 02: Path Diagram

Source: Authors constructed

(c) (7) Kelaniya Journal of Management | 2020| Vol. 09 | Issue 01 | Page 66 